\title{
Study on the Usage and Satisfaction of Mobile Reading Behaviors of College Students -A Case Study of Jd Reading App
}

\author{
Xueyan Cao ${ }^{1,2, a}$, Yiting Feng ${ }^{1, b}$
}

\author{
${ }^{1}$ School of Public Affairs and Administration, Digital Culture and Media Research Center, University \\ of Electronic Science and Technology of China, Chengdu 611731, China \\ ${ }^{2}$ Library, University of Electronic Science and Technology of China, Chengdu 611731, China \\ acaoxy@uestc.edu.cn, ${ }^{b}$ mermaid1996@126.com
}

\begin{abstract}
With the arrival of the era of universal reading, the reading style of the new generation of digital aborigines is also changing. Mobile reading apps are becoming more and more convenient and fragmented ways and platforms for the younger generation to acquire knowledge and read. Based on the specific case study of college students on campus reading App, through questionnaire survey and focus group interviews, peep at the reading motivation and demand satisfaction of college students, reviewing JD reading App (campus version) in between the common types of mobile reading App and academic mobile reading library App, whether can meet the reading needs of students in colleges and universities, and puts forward some corresponding optimization of contemporary college students in China mobile reading behavior model of mobile reading development suggestions.
\end{abstract}

Keywords: mobile reading App, use and satisfaction theory, college students, JD reading App (campus version).

\section{Introduction}

Mobile Internet is convenient and fast, and makes full use of the advantage of fragmentation time, more and more favored by users. In terms of both the breadth of server coverage and the depth of user stickiness, mobile terminal reading is substantially ahead of PC terminal reading, and PC terminal reading space is gradually squeezed. According to the 2018 China digital reading industry research report, readers under the age of 30 account for more than 60 percent, and readers under 35 account for 86.6 percent. In general, the number of young readers is the largest, and digital reading behavior is becoming popular among young people. As the main force of digital reading behavior, the reading behavior of college students in the youth reading group is worth paying attention to. In the physical environment, the relatively closed campus and interpersonal network, and in the virtual network environment, high anonymity and other virtual network characteristics also make the college students group reading environment is special.

At present, various mobile reading apps emerge in an endless stream, including QQ reading, WeChat reading App, Palm reading App, Migu reading App, Netease snail reading App and so on. Different from the general entertainment type of mobile reading App, JD reading campus edition is a multi-terminal in-depth reading platform for college students and teachers. Relying on the resources of JD reading books, it is deeply customized for the campus reading scene. It has columns such as favorite reading, school magazine, reading circle, etc. Besides, it can count the reading duration and classification. Reading forms are diverse, with support for mobile, tablet and computer reading, while JDread, a professional e-ink screen reader, is available. Support ePub, PDF, and other mainstream formats and multimedia e-books, including best sellers and a variety of professional books. All the e-book resources in the platform are authorized by the publishing house, China plate dealer and other relevant copyright holders. So far, the company has reached cooperation with nearly 600 publishing houses in China (including the publishing house and China plate dealer). 


\section{The Research Status}

In recent years, college students group has been rising year by year, mobile reading research including research mobile reading influence factors of college students, social cognition, prefacestructure and countermeasures, including examination of the college students to read different demand analysis, content Zeng Runxi, Chen Chuang in the study found that in college students' differences in supply and demand for mobile reading, (1) the existing supply more difficult to meet college students' motivation of entertainment. Mao Yihong found that the demand rate of college users for professional library reading is higher than that for leisure reading, and the demand rate of users for full-text reading is higher than that for processing and bibliographical reading.

However, according to the research of Ou Jihua et al., friends' information and entertainment information characterized by light reading and floating reading occupy the main position, while learning materials only account for $16.5 \%$. Although this can better meet the emotional expression and recreational motivation of college students, it has little effect on the promotion of personal cultivation and knowledge acquisition motivation relying on deep reading. (2) the existing supply cannot adapt to college students' habit of reading textbooks. Wang Yu et al. also found that college students believe that the advantages of traditional reading are consistent with reading habits, easy to record, conducive to in-depth research, easy to collect, etc., while its disadvantages are not timely search, information cannot be updated, easy to cause physical discomfort, etc. Therefore, mobile reading for college students has formed a natural divide. On the one hand, college students mainly read recreational content through the Internet, mobile phones and other new media, and on the other hand, they read classics and professional knowledge through paper content.

Thus, this study based on JD reading App(campus version), from the perspective of students groups use and satisfaction, the combination of JD version of the campus reading App mobile reading service features, combined with questionnaire and focus group interview way, to look at a variety of research way related factors affecting user satisfaction and behavior intention, reviewing JD reading App(campus version) in between the popularization of mobile reading App and App academic mobile reading library, whether can meet the demand of college students' reading, in order to reference both in theory and practice.

\section{Research Analysis and Conclusion}

According to 1973, Katz, Grewicz and Hess selected 35 needs from the literature on the social and psychological functions of mass media and classified them into five categories: cognitive needs (access to information, knowledge and understanding); Emotional needs (emotional, pleasurable, or aesthetic experiences); The need for personal integration (enhanced credibility, confidence, stability and status); The need for social integration (increased contact with family, friends, etc.); The need to relieve stress (escape and divert attention), as well as people's access to media, is to meet specific needs that have social and personal psychological origins. The author combined these five requirements with the mobile reading needs of college students and sorted out four categories, as shown in table 1:

Table 1. College students mobile reading requirement types

\begin{tabular}{|c|c|c|}
\hline type & Requirement types & Decomposition of demand \\
\hline 1 & Cognitive needs & Access to information, knowledge and understanding \\
\hline 2 & Emotional needs & Mood, pleasure, or the experience of aesthetic feeling, to avoid pressure, \\
relieves stress, etc
\end{tabular}




\subsection{Usage and Satisfaction: Demand and Supply Analysis of JD Reading App (Campus Version)}

According to the survey results, the order of the demands of college students on mobile reading App is from large to small: 2-1-3-4, in which emotional needs and cognitive needs account for more, while personal integration needs and social integration needs account for less. Based on the interviews of the focus group, the following representative interview contents are obtained.

The use of mobile reading apps by college students is mainly for superficial entertainment, and in terms of content selection, the satisfaction of vertical reading needs is the key for college students to choose a certain type of mobile reading apps. Second, for non-entertainment needs, to meet the needs of information and knowledge acquisition, ranked second in the survey results. Generally, college students can only borrow and purchase related physical reading materials through libraries, physical bookstores, etc. If they cannot obtain the printed version of reading materials, they can only search on the web page. Most college students said that in addition to recreational needs, in terms of knowledge and information acquisition of non-recreational needs, for in-depth reading and learning, the existing supply is difficult to meet.

According to the survey, JD reading App(campus version) on the hand is better meet the demand of the deep reading of college students, according to the product introduction of JD reading App(campus version), JD reading resources classification is divided into 37 level, more than three hundred secondary classification, involving philosophy, economics, law, literature, history, medicine, management, more than 10 subjects such as art, industrial technology, the existing more than ten thousand kinds of electronic books in Chinese; In addition, 70\% of the books have been published since 2010, and 1-2 thousand new books are published every week. In terms of deep reading, resource contents similar to JD reading App (campus version) are relatively close to the deep reading needs of college groups.

\subsection{Others: Analysis of the Operation Experience of JD Reading App (Campus Version)}

For mobile reading apps, college students also pay more attention to the experience of reading. Many college students interviewed believe that the page function design of mobile reading apps is also a major factor that influences the satisfaction of using them.

The Apple operating system IOS version of JD reading App (campus version), for example, has specialized in the main category pages, click enter, see page including economic management, social science, film and television works, the novel channel, teaching material, teaching and other kinds of classification of books in the elaboration, the reader may be classified according to the lookup or choose the need to read books. According to the research in this paper, college students have a high degree of satisfaction in the functional design of the App. Satisfying the vertical interests of reading users, such as the classification design of military and youth romance, can help college students to find the content they need more efficiently, and also help the construction of the classification system of knowledge reading for college readers.

Table 2. mobile reading App classification comparison

\begin{tabular}{|c|c|c|c|c|}
\hline & JD reading App (campus version) & $\begin{array}{c}\text { Migu reading } \\
\text { App }\end{array}$ & $\begin{array}{c}\text { Palm reading } \\
\text { App }\end{array}$ & $\begin{array}{l}\text { WeChat } \\
\text { reading App }\end{array}$ \\
\hline $\begin{array}{c}\text { Classified } \\
\text { content }\end{array}$ & $\begin{array}{l}\text { Economic management, social science, film and } \\
\text { television channel original, novel, successful } \\
\text { self-help, computer, leisure life, teaching } \\
\text { material, teaching, scientific information } \\
\text { channel, literature, history, archaeology, } \\
\text { biography, foreign language learning, tutor } \\
\text { parenting, advanced workplace, art, } \\
\text { photography, children's channels, Internet }+ \text {, } \\
\text { Chinese and foreign classics, political and } \\
\text { military, import the original, comic magazines }\end{array}$ & $\begin{array}{l}\text { Writers, boys } \\
\text { and girls, } \\
\text { publishing, } \\
\text { cartoons, } \\
\text { listening, } \\
\text { magazines }\end{array}$ & $\begin{array}{l}\text { Publishing, boys } \\
\text { and girls, } \\
\text { cartoons, } \\
\text { listening, } \\
\text { magazines, a } \\
\text { great god }\end{array}$ & $\begin{array}{l}\text { Novels, } \\
\text { listening, } \\
\text { comics, } \\
\text { publishing, }\end{array}$ \\
\hline
\end{tabular}


In addition, compared with other popular mobile reading Apps, JD reading App (campus version) has a single login and access method, and only a mobile phone login method, while WeChat's reading App, QQ reading App, palm reading App and other mobile reading App login methods can be linked to other platform accounts such as QQ, WeChat, Weibo and so on, making the operation more convenient and efficient.

Table 3. mobile reading App login method

\begin{tabular}{|c|c|c|c|c|}
\hline & $\begin{array}{c}\text { JD reading App } \\
\text { (campus version) }\end{array}$ & Migu reading App & Palm reading App & $\begin{array}{c}\text { WeChat reading } \\
\text { App }\end{array}$ \\
\hline $\begin{array}{c}\text { Login } \\
\text { mode }\end{array}$ & $\begin{array}{c}\text { Phone } \\
\text { verification code } \\
\text { to } \log \text { in }\end{array}$ & $\begin{array}{c}\text { Mobile phone number of a key } \\
\text { account login, account password, } \\
\text { weibo, WeChat, QQ login }\end{array}$ & $\begin{array}{c}\text { Mobile phones authentication } \\
\text { code, account passwords, } \\
\text { WeChat, weibo, QQ login }\end{array}$ & $\begin{array}{c}\text { WeChat, } \\
\text { account } \\
\text { password to log } \\
\text { in }\end{array}$ \\
\hline
\end{tabular}

To sum up, in view of the college students study group of JD reading App (campus version) in the user's use and satisfaction has an advantage also have insufficient, in study on campus, JD reading school edition has a wealth of library resources, including social science, computer and teaching auxiliary books learning resources, and has a high degree of satisfaction with users' knowledge and information acquisition needs. However, JD reading App (campus version) has a large gap with other popular mobile reading apps and even professional novel reading apps, such as Book Flag Reading App and Migu Reading App, in terms of entertainment shallow reading that college students most need, and its satisfaction degree is relatively low. However, in terms of personal integration and social integration, the use demand of mobile reading App is not significant and the difference is not large. Therefore, the author believes that for mobile reading App aimed at college students, it is necessary to strengthen the promotion of resources in shallow reading, and at the same time to think about how to better combine shallow reading with professional knowledge reading.

\section{Research Deficiencies and Prospects}

In conclusion, follow-up studies on mobile reading apps for college students can focus on mobile reading behaviors of this group and further explore influencing factors. At the same time pay attention to observe students groups of mobile reading behavior in different social environment of the new trends, new changes, to probe the causes and consequences of this new trend and new change, continue to increase college students: an empirical study of mobile reading psychology and behavior, in order to help to fully grasp the status quo and development orientation of college students' mobile reading, reading for the mobile industry sustainable and healthy development and provide effective theoretical guidance of university library construction.

\section{Acknowledgements}

This research was financially supported by 2018 reading promotion project of China Library Society "Research on the use and satisfaction of mobile reading app for college students".

\section{References}

[1]. Information on: http://report.iresearch.cn/report/201808/3255.shtml.

[2]. Zeng Runxi, Chen Chuang. Review on Research Progress of Mobile Reading Behavior of College Students [J]. Digital Library Forum, 2017(03):60-67.

[3]. Mao Yi-hong. On Mobile Phone Reading [J]. journal of academic libraries, 2010(6):5-11. 
[4]. Ou Jihua, Luo Zichu, Li Shengsheng. Analysis of the Gap between Supply and Demand of College Students' Digital Reading-An Empirical Survey Based on Digital Reading [J]. Library Science Research, 2016(4):94-101.

[5]. Wang Yu, Li Ziyun. Investigation on the Current Situation of College Students' Digital Reading and Countermeasures [J]. Library Construction, 2013(5):55-59,64. 